\title{
Percepcija kriterija selekcije vijesti kod novinara u hrvatskim dnevnim novinama ${ }^{1}$
}

\author{
Tanja Grmuša* \\ Goran Popović*** \\ Mihaela Banek Zorica ${ }^{* * *}$
}

\section{SAŽETAK}

Selekcija vijesti u središtu je proučavanja brojnih autora, posebice zbog promjenjivosti faktora vrijednosti vijesti koji utječu na novinarsku odluku o tome koji će događaj biti objavljen. No, većina dosadašnjih autora taj proces razmatra s teorijskog aspekta (Galtung i Ruge, 1965; Schulz, 1975; Gans, 1980), dok je vrlo malo empirijskih provjera (Kanižaj, 2010; Perišin, 2010; Prpić, Popović, Hadžić, 2011). Poseban izazov pritom predstavlja praćenje specifičnih područja, kao EU tematike, koja nerijetko ostaje u sjeni nacionalne tematike. Rad donosi rezultate istraživanja indikatora selekcije vijesti podijeljenih na unutarnje $i$ vanjske kriterije, čiju su prikladnost i primjenjivost u sklopu predloženoga modela (pr) ocjenjivali novinari redakcija šest najčitanijih dnevnih novina - Jutarnjeg lista, Večernjeg lista, 24 sata, Novog lista i Slobodne Dalmacije krajem listopada $i$ početkom studenoga 2014. godine. Istraživanje provedeno metodom online ankete na uzorku od $N=62$ novinara podijeljenih $u$ dvije skupine - novinari koji prate EU tematiku i novinari koji prate ostale teme, pokazalo je da novinari zamišljeni teorijski koncept procjenjuju u sirem kontekstu profesionalnih standarda. Isto-

\footnotetext{
* Dr. sc. Tanja Grmuša, Visoka poslovna škola Zagreb s pravom javnosti, Ulica grada Vukovara 68, 10000 Zagreb, Katedra za komunikacije, e-adresa: tanja.grmusa@vpsz.hr ${ }^{* *}$ Izv. prof. dr. sc. Goran Popović, prof. v. š., Veleučilište Baltazar, Ulica Vladimira Novaka 23, 10290 Zaprešić, Katedra za informacijske i komunikacijske znanosti, voditelj specijalističkog diplomskog stručnog studija 'Komunikacijski menadžment', e-adresa: goran.popovic@bak.hr

*** Izv. prof. dr. sc. Mihaela Banek Zorica, Filozofski fakultet Sveučilišta u Zagrebu, Ulica Ivana Lučića 3, 10000 Zagreb, Katedra za medije i komunikologiju, e-adresa:mbanek@ffzg.hr
} 
Medij. istraž. (god. 22, br. 2) 2016. (27-43)

dobno, rezultati su pokazali kako nema značajnijih razlika između novinara šest promatranih redakcija, no prema prosječnim rezultatima utvrđene su razlike $u$ odabiru sljedećih kriterija: pristranost vs. nepristranost, personalizacija i ljudski interes, urednicka politika, utjecaj elitnih osoba i elitnih nacija te utjecaj interesnih skupina. Također, utvrđene su i razlike između novinara koji prate EU $i$ novinara koji prate ostale teme u četiri ispitana indikatora: ljudski interes i personalizacija, integrirana redakcija te globalni vs. regionalni događaji.

Ključne riječi: selekcija vijesti, vrijednost vijesti, EU tematika, dnevne novine, novinari

\section{Uvod}

Odgovori na pitanja što utječe na odabir vijesti, zatim što tvori događaj ili koji su razlozi da neka vijest bude objavljena nisu jednoznačni, ističe Perišin (usp. 2010, 123), a pojedini medijski djelatnici u želji za personalizacijom i dramatizacijom događaja nerijetko zaborave na bit samog događaja. Da bi događaj postao viješću, nije dovoljno imati samo elemente vijesti, već na njegov odabir utječu i brojni različiti čimbenici zbog čega se i ističe razlika između svojstava događaja i svojstava vijesti. No, usprkos tomu postoje događaji koji postaju vijestima, ali nemaju visoku informativnu vrijednost (usp. Perišin, 2010, 123). Teorija je definirala kriterije koji utječu na novinarski i urednički odabir, no Perišin naglašava kako nema prevelike razlike u selekciji vijesti na televiziji i u tisku. Termin vrijednost vijesti u literaturi egzistira sinonimno sa sljedećim pojmovima: informativne vrijednosti i informativni faktori, a riječ je o subjektivnim i intuitivnim procjenama novinara o tome što zanima publiku. Proces selekcije vijesti važan je za teoretičare, ali i praktičare, kako bi se mogao i iskustveno razumjeti proces donošenja odluka u redakciji. Na odabir vijesti nesumnjivo utječu unutarnji i vanjski faktori, tj. čimbenici unutar redakcije, ali i izvan nje (usp. Östgaard, 1965; Gans, 2004, 79 prema Perišin, 2010, 124). Proces selekcije vijesti može se promatrati kroz prizmu tehnoloških, ekonomskih i političkih uvjeta, no mi ćemo se u daljnjem radu baviti profesionalnim kriterijima te njihovoj percepciji kod novinara, koji na taj način kreiraju svoje objave i odlučuju o čemu će nas informirati na dnevnoj bazi.

\section{Selekcija vijesti u dnevnim novinama - kako udovoljiti različitim interesnim skupinama?}

Društvene i redakcijske promjene odražavaju se i na raznolikost medijskog sadržaja, pri čemu pitanje vrijednosti vijesti postaje sve aktualnije u kontekstu novih teh- 
Percepcija kriterija selekcije vijesti kod novinara u hrvatskim dnevnim novinama

nologija. Pojava građanskog novinarstva te procesi konvergencije medija osnažili su ulogu konzumenata i ubrzali proizvodni proces nastanka vijesti, a to nesumnjivo utječe na raznolikost medijskog sadržaja i njegovu percipiranu vrijednost u kontekstu profesionalnih standarda (usp. Vilović, 2011). Stvaranje vrijednosti za publiku nerijetko podrazumijeva zadovoljavanje različitih interesa, pri čemu je prva dvojba odabir između tvrdih i mekih vijesti te pronalaženje ravnoteže između kratkih i dugih medijskih formi. Povijesni pregled kriterija selekcije vijesti pokazuje kako je riječ o procesu aktualnome još u 17. Stoljeću, kada je Tobias Peucer analizirao što je vrijedno objavljivanja. Njegovim putovima nastavljaju i Walter Lipmann 1922. razlikujući pseudosvijet od stvarnoga svijeta te Kurt Lewin 1947. s analizom uloge gatekeepera u medijima, koju je 1964. prvi empirijski provjerio David Maning White u studiji o Mr. Gatesu (Kunczik, Zipfel, 2006). No, model 12 informativnih faktora ${ }^{2}$, koji su 1965. postavili Galtung i Ruge, već dugo čini temelj za preispitivanje i dopunu modela (Tunstall, 1971; Peterson, 1979; Hetherington, 1985; Herbert, 2000), jednako kao i Gansove (1980) četiri teorije selekcije vijesti (1) novinarski orijentirana teorija, 2) teorija selekcije u kontekstu organizacije, 3) teorija zrcala, 4) teorija prema kojoj na selekciju utječu snage izvan uredništva), kao jedne od najcitiranijih u teoriji novinarstva. Harcup i O'Neill (2001) model Galtunga i Ruge smatraju ograničavajućim zbog isključivog fokusa na strane vijesti i izvještavanje o događajima. Analizirajući izvještavanje triju vodećih britanskih dnevnih novina ${ }^{3}$, zaključili su kako analiza faktora vrijednosti vijesti više govori o kvaliteti pokrivenosti događaja, nego o novinarskom odabiru. ${ }^{4}$

Prve empirijske provjere modela selekcije vijesti u hrvatskim redakcijama možemo pratiti tek nakon 2000-ih (Kanižaj, 2010; Perišin 2010; Prpić, Popović, Hadžić, 2011). Odabir vijesti kod novinara i kod publike odvija se prema različitim kriterijima, a može se proučavati s kognitivno-psihološkog te sociopsihološkog aspekta. Na novinarskoj strani svakako treba istaknuti utjecaj osobnog sustava vrijednosti (Weaver i Wilhoit, 1997 prema Donsbach, 2004), zatim utjecaj ključnih događaja poput prometnih nesreća i terorizma te izvora i PR strategija. To je u skladu i s Tuchmannovim (1978 prema Kanižaj, 2010) stavom kako nema nepristrane selekcije, već je sve na uredništvu. S druge strane, odabir vijesti kod publike vođen je različitim motivacijama, pri čemu se ističe trend konzumacije negativnih vijesti neovisno o kojem je području djelovanja riječ (usp. Lee i Chyi, 2014). Sličan obrazac medijskog izvještavanja uočava se i kod praćenja EU tematike, što je bilo izraženo u tradicionalno euroskeptičnom britanskom tisku tijekom praćenja višemjesečne kampanje za izlazak Britanije iz EU-a. ${ }^{5}$

Zastupljenost EU vijesti u hrvatskim je medijima uglavnom marginalizirana, ponajviše zbog dominantno protokolarnog izvještavanja, ali i nezainteresiranosti novinara za praćenje EU tematike (usp. Popović, Grmuša, Prpić, 2011; Popović, Grmuša, Prpić, 2012; Popović, Grmuša, Prpić, 2014). Prikaz EU-a do sada se 
uglavnom proučavao kroz koncept framinga, budući da se vjeruje da okvir konflikta, ljudskog interesa te odgovornosti utječe i na percepciju EU-a u javnosti. Model proučavanja europskih diskursa koji su razvili Heikkilä i Kunelius pokazuje da na njihovu primjenu utječu novinarov osobni sustav vrijednosti, status u mediju, elementi korporativne kulture, kao i politički položaj njihove zemlje u EU (usp. Heikkilä i Kunelius 2006, 68). Zastupljenost EU tema u Hrvatskoj, kao najmlađoj članici EU-a, treba biti dio društvenog i medijskog diskursa, stoga je u procesu kreiranja medijskih objava važan odabir kriterija selekcije vijesti koji se razlikuje ovisno o rubrici/području koje se prati, pri čemu se novinari vode korisničkim preferencijama i kreativnošću (usp. Picard, 2010).

\section{Redefiniranje informativnih faktora u svrhu istraživanja percepcije indikatora selekcije vijesti kod novinara u hrvatskim dnevnim novinama}

Spomenuti trendovi poticaj su za kontinuirano preispitivanje informativnih vrijednosti u medijima, koje mogu biti umanjene posebice kada je riječ o događajima u kontinuitetu, kao što je primjerice bio slučaj s hrvatskim eurointegracijskim putem koji je trajao gotovo čitavo desetljeće. Veliki je to izazov ponajprije zbog očuvanja informacijske vrijednosti, ali i neprestane potrage za zanimljivostima u sklopu teme koja možda predstavlja zasićenje kod novinara, ali i kod publike. Podsjetimo, nije svaka informacija vrijedna objavljivanja, a na njen odabir utječu prije svega kriteriji informacijske vrijednosti. Posredovanje informacija jedna je od djelatnosti medija, a njihov odabir utječe i na percepciju pojedinoga događaja kod publike, kao i što pridonosi informiranosti publike o njemu. Sve navedeno motiviralo nas je da na temelju postojećih teorijskih modela kriterija selekcije vijesti, te polazeći od najcitiranijeg modela Galtunga i Rugea (1965), redefiniramo neke informativne faktore utjecaja na vrijednost vijesti te provjerimo njihovu percepciju kod novinara u šest redakcija hrvatskih dnevnih novina. Praćenje EU tema u hrvatskim dnevnim novinama u posljednjih nekoliko godina potaknulo nas je da percepciju indikatora selekcije vijesti provjerimo kod novinara koji prate EU tematiku i novinara koji prate ostala područja, kako bismo prepoznali i razumjeli razlike u njihovu odabiru. Indikatore smo svrstali u dvije skupine - unutarnji $i$ vanjski kriteriji, pri čemu smo u unutarnje kriterije ubrojili osobne stavove novinara, njihovu ideološku pripadnost, uravnoteženost/nepristranost, ljudski interes, personalizaciju, uredničku politiku, ustroj medijske organizacije, a u vanjske kriterije medijsko vlasništvo, veličinu medija, zakonodavni okvir, integriranu redakciju, blizinu, važnost, posljedice/ doseg, kontinuitet izvještavanja, sukob/kontroverznost/negativnost/senzacionalizam, aktualnost, utjecaj elitne osobe/utjecaj elitne nacije, interesne skupine (PR, oglašivači, izvori informacija). 
Percepcija kriterija selekcije vijesti kod novinara u hrvatskim dnevnim novinama

\section{Istraživanje percepcije kriterija selekcije vijesti u hrvatskim dnevnim novinama}

Budući da postoje brojni teorijski koncepti selekcije vijesti, glavni je cilj ovog dijela istraživanja bio provjeriti kako ti zamišljeni koncepti funkcioniraju u novinarskoj praksi u hrvatskim dnevnim novinama. Prvo pitanje koje se nameće je poistovjećuju li novinari način odabira vijesti u svojoj praksi sa zamišljenim teorijskim konceptom. Nadalje, cilj je bio ispitati razlikuju li se po tom pitanju međusobno prakse: a) novinara koji izvještavaju o EU u odnosu na one novinare koji ne izvještavaju o EU; zatim razlikuju li se prakse b) novinara između šest najčitanijih nacionalnih $\mathrm{i}$ regionalnih tiskovina. Budući da u Hrvatskoj (na uzorku novinara) ovakav teorijski model nije testiran anketnim upitnikom, važno je naglasiti da je opseg ovog istraživanja eksploratoran uz adekvatne statističke procedure opisane kasnije u radu.

\section{Metoda i postupak}

Prvi dio istraživanja odrađen je metodom online anketiranja novinara. Pretpostavke za primjenu ovakvog tipa ankete odnose se na osobine populacije koja se istražuje (novinari nacionalnih i regionalnih dnevnih novina), osiguravanje pouzdanosti (sigurnost da je anketu ispunila osoba kojoj je ona i namijenjena), mala pristranost u odgovorima ispitanika, veličina uzorka i zemljopisna raspršenost ispitanika, relativno maleni troškovi provedbe, smanjena mogućnost pristranosti istraživača, kao i automatsko unošenje podataka što olakšava pristup ispitanicima, a kasnije i obradu podataka istraživačima (usp. Tkalac Verčič i sur., 2013, 104). Regrutacija ispitanika po redakcijama šest dnevnih novina - Jutarnjeg lista, Večernjeg lista, 24 sata, Slobodne Dalmacije, Novog lista i Glasa Slavonije odvijala se strogo kontrolirano u kontekstu praćenja novinara koji će ući u uzorak (novinari koji prate EU tematiku i novinari koji prate ostale teme), pri čemu je istraživač birao kome će poslati anketu prema strogo zadanom nacrtu. Svakom ispitaniku dodijeljen je kod (npr. PW34Y) koji je zamjenjivao njegov/njezin identitet u bazi podataka, te omogućio istraživaču lakše praćenje odaziva po redakcijama na dnevnoj razini. Anketa je bila aktivna dva tjedna (30. 10. 2014. - 17. 11. 2014.) i dobiveni su rezultati $\mathrm{N}=62$ ispitanika. Upitnik je sadržavao ukupno $\mathrm{N}=59$ tvrdnji, $\mathrm{N}=22$ kojima smo ispitivali unutarnje kriterije te $\mathrm{N}=37$ kojima smo ispitivali vanjske kriterije. Novinari su (pr)ocjenjivali važnost pojedinih kriterija odabira vijesti prema informativnoj vrijednosti. Kriteriji su podijeljeni na unutarnje i vanjske prema priloženoj teorijskoj shemi i operacionalnim česticama na kojima je bio temeljen anketni upitnik. Prikazane čestice inkorporirane su u anketni upitnik, tako da je uz 
svaku česticu pridružena Likertova skala od 1 do 5 (1 = najmanji stupanj slaganja s česticom; 5 = najveći stupanj slaganja s česticom). Zavisnu varijablu pritom predstavlja važnost pojedinoga od ispitivanih kriterija selekcije vijesti na novinarsku praksu, dok nezavisnu varijablu čine dva kriterija; 1) dnevne novine iz kojih novinari dolaze i 2) dvije skupine novinara - oni koji se bave EU tematikom i oni koji se ne bave EU tematikom. Prilikom korištenja Likertove ljestvice nužno je izvijestiti o Cronbach alpha koeficijentu (Gliem i Gliem, 2003) koji govori o unutarnjoj konzistentnosti instrumenta. Riječ je o koeficijentu koji procjenjuje unutarnju konzistentnost i pouzdanost mjernog instrumenta, određujući kako će se ostali predmeti u instrumentu ponašati u odnosu na ostale predmete u mjernom instrumentu (usp. Gay, Mills i Airaisan, 2006, 141 - 142 prema Croasmun, Ostrom, 2011, 20). Za određivanje dimenzionalnosti ljestvice koristila se faktorska analiza.

Sve čestice/tvrdnje derivirane su iz teorijski postavljenih i definiranih indikatora unutarnjih i vanjskih kriterija selekcije vijesti. Treba istaknuti još jedan metodološki problem u vidu operacionalizacije teorijski zamišljenih dimenzija kriterija selekcije vijesti. Iako se nastojalo obuhvatiti sve teorijske indikatore u upitniku, očekivano je da u ovakvim teorijskim konceptima, neke dimenzije sadržavaju veću razinu operacionalne i empirijske provjerljivosti od drugih, no cilj je bio obuhvatiti teorijski koncept u cijelosti i provjeriti kako zamišljene dimenzije funkcioniraju u novinarskoj praksi u Hrvatskoj.

\section{Rezultati i diskusija}

\section{Unutarnji kriteriji selekcije}

Unutarnji kriteriji selekcije vijesti teorijski su grupirani u četiri dimenzije: 1) Pristranost vs. nepristranost, 2) Ljudski interes i personalizacija, 3) Urednička politika te 4) Ustroj medijske organizacije. Cilj je bio utvrditi i provjeriti kako ovaj teorijski model funkcionira u praksi kada se o njemu izjašnjavaju i iskazuju svoje stavove i mišljenja novinari šest najčitanijih dnevnih tiskovina. Rezultati su iskazani na jednak način za svaku testiranu dimenziju zamišljenu prema teorijskom konceptu: a) iskazano je koliko posto (\%) varijance objašnjavaju varijable unutar svake zasebne dimenzije; b) iskazan je Cronbachov $\alpha$ koeficijent kao mjera pouzdanosti (prosječna korelacija varijabli kojima smo mjerili svaku pojedinu dimenziju) i kojim iskazujemo unutarnju homogenost svake zamišljene dimenzije.

Prva dimenzija „Pristranost vs. nepristranost ${ }^{66} \mathrm{u}$ izvještavanju ispitivana je kao dvosmjerna dimenzija, budući da teorija predlaže takvu klasifikaciju: a) pristranost kao osobni stav autora te b) pristranost kroz simpatiziranje određene političke opcije. No, budući da se u oba slučaja radi o nekom obliku pristranog vs. nepristranog 
Percepcija kriterija selekcije vijesti kod novinara u hrvatskim dnevnim novinama

izvještavanja, konceptualno se zapravo radi o jednoj dimenziji sa sljedećim indikatorima: novinarsko zauzimanje strane, oslanjanje na samo jedan izvor, oslanjanje na izvore koji se međusobno slažu u stavovima, isticanje osobne ideološke pripadnosti, nesklonost podupiranju političkih opcija koje novinar privatno ne podupire, nedovoljno razdvajanje informacije od stava, uravnoteženost isticanja citata svih suprotstavljenih strana u autorskim člancima. Rezultati analize glavnih komponenti pokazali su da ovih sedam varijabli objašnjava 33,729 \% ukupne varijance dimenzije „Pristranost vs. nepristranost“. Pouzdanost čestica (Cronbach alpha) iznosi .659 u čitavom uzorku $(\mathrm{N}=62)$. Ova je analiza pokazala prihvatljivu unutarnju konzistentnost dimenzije "'Pristranost vs. nepristranost."

Druga dimenzija u sklopu unutarnjih kriterija, „Ljudski interes i personalizacija“ ispitivana je indikatorima: iznenadni uspjesi istaknutih pojedinaca, manjinske društvene skupine, osobna uključenost novinara u priču i perspektiva ,malih ljudi“/ običnih građana. Rezultati analize glavnih komponenti pokazali su da tri varijable, kojima je mjerena ova dimenzija, objašnjavaju 48,223 \% ukupne varijance dimenzije „Ljudski interes i personalizacija“. Pouzdanost čestica (Cronbach alpha) iznosi ,458 u čitavom uzorku $(\mathrm{N}=62)$. Ova je analiza pokazala nisku unutarnju konzistentnost dimenzije, na što je utjecao i mali broj čestica ove dimenzije. S druge strane, analize glavnih komponenti pokazuju da tri varijable kojima smo mjerili ovu dimenziju, objašnjavaju 48,223 \% ukupne varijance što je bolji rezultat, nego u dimenziji pristranost vs. nepristranost, iako ona ima unutarnju konzistentnost na razini prihvatljivog, dok je unutarnja homogenost dimenzije ljudskih interesa i personalizacije na granici prihvatljivog.

Treća dimenzija, „Urednička politika“ ispitivana je sljedećim indikatorima: urednički odabir i utjecaj, korištenje drugih medija kao izvora, poštivanje profesionalnih standarda, te osiguravanje podjednake zastupljenosti svih aktera priče zahvaljujući uredničkoj politici. Rezultati analize glavnih komponenti pokazali su da tri varijable kojima smo mjerili ovu dimenziju, objašnjavaju 51,478 \% ukupne varijance dimenzije „Urednička politika“. Pouzdanost čestica (Cronbach alpha) iznosi ,526 u čitavom uzorku $(\mathrm{N}=62)$. Iako navedeni indikatori objašnjavaju 51,478 \% ukupne varijance, utvrđena je relativno niska unutarnja konzistentnost dimenzije, na što je utjecao i mali broj čestica ove dimenzije. Novinari, dakle, donekle povezuju tri aspekta uredničke politike kako je teorijski zamišljeno, no čitava dimenzija sadrži tri pokazatelja koji ne moraju nužno u novinarskoj praksi biti percipirani kao izravan dio uredničke politike. Korištenje drugih medija kao izvora te poštivanje profesionalnih standarda i normi struke, mogu se smatrati i razraditi kao zasebne dimenzije. Ovako definirana dimenzija zapravo ukazuje na razne aspekte poštivanja standarda struke te se stoga predlaže proširenje naziva na „Uredničku politiku i profesionalne standarde“. Naime, novinari ne smatraju da su u praksi skloni najčešće 
uzimati druge medije kao izvore, urednici osiguravaju podjednaku zastupljenost svih aktera teme, a profesionalni se standardi u prezentaciji teme općenito poštuju. Četvrta ispitivana dimenziju u sklopu unutarnjih kriterija, „Ustroj medijske organizacije“ ispitivana je indikatorima: doprinos medija procesu demokratizacije društva, javni interes, kritika vladajućih elita, komercijalno usmjerenje privatnih medija, utjecaj oglašivača te civilno društvo i pluralizam kroz vlasničku strukturu. Rezultati analize glavnih komponenti pokazuju da pet varijabli kojima smo mjerili ovu dimenziju, objašnjavaju 46,312 \% ukupne varijance dimenzije „Ustroj medijske organizacije“. Pouzdanost čestica (Cronbach alpha) iznosi ,694 u čitavom uzorku $(\mathrm{N}=62)$. Analiza je pokazala prihvatljivu razinu unutarnje konzistentnosti dimenzije. Novinari su povezali svih pet aspekata ustroja medijske organizacije kako je teorijski zamišljeno, no čitava dimenzija, čini se, ukazuje na jedan sasvim drugi aspekt, stoga je potrebna redefinicija dimenzije i promjena termina na „Javni interes“. Naime, svi mjereni aspekti odnose se upravo na javni interes, kao nešto na što se mediji i novinari trebaju fokusirati kroz odabir tema, bilo da se radi o jačanju procesa demokratizacije ili kritici vladajućih struktura (ispitanici aktivnost domaćih medija vide nedovoljnom u ispunjenju ovog kriterija).

\section{Vanjski kriteriji selekcije}

Prva teorijska dimenzija vanjskih kriterija „Medijsko vlasništvo“ ispitivana je preko indikatora: financiranje javnih medija iz javnih sredstava kao garancija kritičkog izvještavanja i uspostavljanja dijaloga s građanima te financiranje privatnih medija kao uzrok zanemarivanju javnog interesa. Druga teorijska dimenzija „Veličina medija“ ispitivana je preko indikatora: nacionalni mediji kao bolji prezenteri teme u odnosu na regionalne; međunarodno vlasništvo domaćih medija kao dodatni uvjet bržeg dopiranja do publike. Rezultati analize glavnih komponenti pokazuju da četiri varijable medijskog vlasništva i veličine medija zajedno objašnjavaju 39,321 \% ukupne varijance zajedničke dimenzije. Pouzdanost čestica (Cronbach alpha) iznosi ,477 u čitavom uzorku ( $N=62)$. S obzirom na ovakve rezultate možemo zaključiti da ove dvije teorijske dimenzije u novinarskoj praksi u Hrvatskoj treba promatrati kao jednu zajedničku dimenziju, uz redefiniranje njenog značenja i naziva. Stoga se logičnim čini objedinjavanje ovih dimenzija u jednu, naziva „Utjecaj vlasništva i dosega medija na kvalitetu i obuhvat izvještavanja“. Ova je analiza pokazala graničnu razinu spomenute unutarnje konzistentnosti dimenzije jer pokazuje razne aspekte utjecaja vlasništva i dosega medija na opseg i kvalitetu izvještavanja. Novinari zapravo i ovdje ,reagiraju“ na implikacije pravilnog ispunjavanja funkcija i standarda struke - kritičko izvještavanje o društvenim nepravilnostima, uspostava dijaloga s građanima, adekvatno i sveobuhvatno predstavljanje teme ako se radi o nacionalnim medijima, te malen utjecaj stranog vlasništva. 
Percepcija kriterija selekcije vijesti kod novinara u hrvatskim dnevnim novinama

Teorijska dimenzija „Zakonodavni okvir“, ispitivana je preko indikatora: autocenzura, uređenost pitanja medijskog djelovanja i provođenje samovolje vlasnika. Rezultati analize glavnih komponenti pokazuju da tri varijable medijskog vlasništva i veličine medija zajedno objašnjavaju 42,883 \% ukupne varijance zajedničke dimenzije. No, pouzdanost čestica (Cronbach alpha) iznosi ,321 u čitavom uzorku $(\mathrm{N}=62)$. Takav rezultat ukazuje na neprihvatljivu razinu unutarnje homogenosti ove dimenzije: ispitani novinari nisu percipirali ova tri aspekta kao zajedničke pokazatelje zakonodavnog okvira. Ovu dimenziju potrebno je redefinirati te u idućim istraživanjima razraditi kroz drugačije operacionalizirane i konceptualizirane indikatore. Naime, izraženost autocenzure u tiskanim se medijima fokusira na odnos tiskanih i elektroničkih medija, a manje na sam zakonodavni okvir, iako je implicitno autocenzura svakako pokazatelj kako funkcionira zakonodavstvo vezano uz novinarsku praksu. Slično tome, samovolja vlasnika, koja je teorijski zasigurno problem medijske regulacije, fokusirana je u ovom upitniku na odnos novinara $i$ redakcije s vlasnicima medija.

Dimenzija „Integrirana redakcija“ ispitivana je indikatorima: povezanost redakcija tiskanog i online izdanja kao (pred)uvjet kvalitetnije medijske produkcije, smanjenja troškova i većeg dosega. Rezultati analize glavnih komponenti pokazuju da tri varijable kojima smo mjerili ovu dimenziju, objašnjavaju 51,842 \% ukupne varijance dimenzije ,Integrirana redakcija“. Pouzdanost čestica (Cronbach alpha) iznosi ,528 u čitavom uzorku ( $\mathrm{N}=62)$. Iako one objašnjavaju 51,478 \% ukupne varijance, analiza je pokazala relativno nisku unutarnju konzistentnost dimenzije, na što je utjecao mali broj čestica ove dimenzije. Novinari donekle povezuju sva tri aspekta integrirane redakcije, kako je teorijski zamišljeno. Ovako definirana dimenzija zapravo ukazuje na razne korisne aspekte poštivanja standarda struke. Očekivano je da će novinari potvrditi ono što je dosadašnja praksa već pokazala integriranje online i tiskane redakcije realno smanjuje troškove, budući da isti autori objavljuju istu vijest u oba izdanja, a i cijena online produkcije značajno je manja. Nadalje, povezanost redakcija zbog lakše komunikacije doprinosi i kvalitetnijem izvještavanju. Na kraju, korištenje novih medija (internet, društvene mreže) generira i porast broja konzumenata pa uvođenje online izdanja uz tiskano izdanje povećava doseg vijesti te je također potrebna redefinicija na „Koristi i prednosti integrirane redakcije“".

Rezultati ispitivanja teorijskih dimenzija ,Važnost događaja“ i ' Aktualnost, blizina i doseg događaja" pokazali su da četiri varijable važnosti, aktualnosti, blizine i dosega događaja zajedno objašnjavaju 36,080 \% ukupne varijance zajedničke dimenzije. Pouzdanost čestica (Cronbach alpha) iznosi ,393 u čitavom uzorku $(\mathrm{N}=62)$. S obzirom na ovakve rezultate, možemo prije svega zaključiti kako je ove dvije teorijske dimenzije u novinarskoj praksi u Hrvatskoj, moguće promatrati kao 
jednu zajedničku dimenziju, uz redefiniranje njenog značenja i naziva na „Globalni vs. regionalni događaji“،. Osim toga, raspodjela faktorskih opterećenja pokazala je kako su novinari prednost uglavnom dali globalnim, u odnosu na regionalne i ostale događaje. Dimenzija teorijskog naziva „Posljedice događaja“ ispitivana je indikatorima: materijalne posljedice i gubitak ljudskih života, a dimenzija „Kontinuitet događaja" indikatorima: kontinuitet u odnosu na jednokratnost i kontekstualnost događaja. Rezultati analize glavnih komponenti pokazuju da sve četiri varijable posljedica i kontinuiteta događaja zajedno objašnjavaju 45,144 \% ukupne varijance zajedničke dimenzije. Pouzdanost čestica (Cronbach alpha) iznosi ,543 u čitavom uzorku (N=62). S obzirom na ovakve rezultate, može se zaključiti kako je ove dvije teorijske dimenzije u novinarskoj praksi u Hrvatskoj moguće promatrati kao jednu zajedničku dimenziju, uz dodatno definiranje njenog značenja i naziva. Raspodjela faktorskih opterećenja pokazuje kako su novinari prednost uglavnom dali kontinuiranim događajima te događajima koji impliciraju gubitke ljudskih života i događaje sa značajnim materijalnim posljedicama. Ipak, analiza je pokazala relativno nisku unutarnju konzistentnost dimenzije. Stoga se i ovdje predlaže prošireni naziv „Vrste događaja prema posljedicama i kontinuitetu“, uz daljnju razradu navedenih aspekata materijalnih i ljudskih posljedica te kontinuiteta vijesti, kao glavnih indikatora utjecaja vrste događaja na selekciju vijesti.

Sljedeća dimenzija „Elitne osobe i elitne nacije“ ispitivana je indikatorima: gospodarski razvijenija i politički naprednija nacija ima prednost u izvještavanju te istaknuti pojedinci iz društvenog i političkog života imaju prednost u izvještavanju. Rezultati analize glavnih komponenti pokazuju da tri varijable kojima smo mjerili ovu dimenziju objašnjavaju 58,638 \% ukupne varijance dimenzije „Elitne osobe i elitne nacije“. Pouzdanost čestica (Cronbach alpha) iznosi ,647 u čitavom uzorku $(\mathrm{N}=62)$. Analiza je pokazala prihvatljivu razinu unutarnje konzistentnosti dimenzije. Novinari, dakle, povezuju tri aspekta utjecaja elitnih osoba i elitnih nacija na odabir tema, kako je teorijski zamišljeno. Ispitani novinari pokazali su visok stupanj slaganja s postavljenim tvrdnjama te potvrdili kako kriterij elitnih osoba i elitnih nacija funkcionira kao važan u odabiru teme i u njihovoj praksi.

Dimenzija „Interesne skupine“, ispitivana preko indikatora koji ukazuju na utjecaj PR stručnjaka i oglašivača na odabir tema, pokazuje da tri varijable korištene za mjerenje objašnjavaju 47,615 \% ukupne varijance dimenzije „Interesne skupine“. Pouzdanost čestica (Cronbach alpha) iznosi ,439 u čitavom uzorku (N=62). Analiza je pokazala neprihvatljivu razinu unutarnje konzistentnosti dimenzije. Novinari, dakle, slabo povezuju tri aspekta utjecaja interesnih skupina na odabir tema u odnosu na teorijski koncept. No, iskazuju i relativno slaganje s postavljenim tvrdnjama te potvrđuju kako PR stručnjaci i oglašivači imaju utjecaj na kreiranje objava, kako plaćenih, tako i neplaćenih. 
Percepcija kriterija selekcije vijesti kod novinara u hrvatskim dnevnim novinama

Tablica 1. Prosječni rezultati prema redakcijama s utvrđenim značajnim razlikama ANOVA testom na uzorku od 62 ispitanika.

Table 1. ??????

??

\begin{tabular}{|c|c|c|c|c|}
\hline & & Br. isp. & Prosjek & Std. Dev. \\
\hline \multirow{7}{*}{$\begin{array}{l}\text { Pristranost } \\
\text { vs. nepristranost }\end{array}$} & Jutarnji list & 12 & 2,845 & ,20620 \\
\hline & Večernji list & 14 & 3,225 &, 73852 \\
\hline & 24 sata & 10 & 2,671 & 62470 \\
\hline & Novi list & 8 & 3,536 &, 54932 \\
\hline & Slobodna Dalmacija & 8 & 3,071 &, 48894 \\
\hline & Glas Slavonije & 10 & 2,943 & 63959 \\
\hline & Ukupno & 62 & 3,037 & ,61264 \\
\hline \multirow{7}{*}{$\begin{array}{l}\text { Personalizacija } \\
\text { i ljudski interes }\end{array}$} & Jutarnji list & 12 & 3,083 &, 76706 \\
\hline & Večernji list & 14 & 2,691 & ,53051 \\
\hline & 24 sata & 10 & 3,600 & ,46614 \\
\hline & Novi list & 8 & 3,250 & ,63621 \\
\hline & Slobodna Dalmacija & 8 & 3,500 &, 75593 \\
\hline & Glas Slavonije & 10 & 3,133 & 83444 \\
\hline & Ukupno & 62 & 3,161 &, 71605 \\
\hline \multirow[t]{7}{*}{ Urednička politika } & Jutarnji list & 12 & 2,833 &, 71774 \\
\hline & Večernji list & 14 & 2,429 &, 76715 \\
\hline & 24 sata & 10 & 3,400 & 53978 \\
\hline & Novi list & 8 & 2,333 & ,59094 \\
\hline & Slobodna Dalmacija & 8 & 2,792 & 43416 \\
\hline & Glas Slavonije & 10 & 2,667 & 88889 \\
\hline & Ukupno & 62 & 2,737 &, 74691 \\
\hline \multirow{7}{*}{$\begin{array}{l}\text { Utjecaj elitnih osoba } \\
\text { i nacija }\end{array}$} & Jutarnji list & 12 & 3,556 &, 47849 \\
\hline & Večernji list & 14 & 3,905 & ,52993 \\
\hline & 24 sata & 10 & 2,800 & ,65168 \\
\hline & Novi list & 8 & 3,875 &, 73328 \\
\hline & Slobodna Dalmacija & 8 & 3,167 & 1,25988 \\
\hline & Glas Slavonije & 10 & 3,167 & 68943 \\
\hline & Ukupno & 62 & 3,441 & 80249 \\
\hline \multirow{7}{*}{$\begin{array}{l}\text { Utjecaj interesnih } \\
\text { skupina }\end{array}$} & Jutarnji list & 12 & 3,278 & ,44571 \\
\hline & Večernji list & 14 & 3,595 & 69404 \\
\hline & 24 sata & 10 & 2,967 & ,65640 \\
\hline & Novi list & 8 & 3,542 & ,95846 \\
\hline & Slobodna Dalmacija & 8 & 4,000 & 69007 \\
\hline & Glas Slavonije & 10 & 3,733 & ,68132 \\
\hline & Ukupno & 62 & 3,500 &, 72867 \\
\hline
\end{tabular}


Konačno, dimenzija „Senzacionalizam“ ispitivana je indikatorima: sklonost izvještavanju o sukobima, poticanje konflikta javnih osoba, teme koje izazivaju društvene podjele, negativni događaji i loše vijesti, izvlačenje događaja iz konteksta, subjektivna novinarska interpretacija, oslanjanje na anonimne izvore, kleveta i narušavanje časti pojedinaca te objavljivanje tajnih dokumenata. Rezultati analize glavnih komponenti pokazuju da devet varijabli, kojima je mjerena ova dimenzija, objašnjava 37,066 \% ukupne varijance dimenzije „Senzacionalizam“. Pouzdanost čestica (Cronbach alpha) iznosi ,773 u čitavom uzorku $(\mathrm{N}=62)$. Novinari, dakle, povezuju devet aspekata senzacionalizma kako je teorijski zamišljeno.

\section{Razlike između šest analiziranih redakcija}

Kako bi se utvrdilo postoji li razlika između šest analiziranih redakcija (Jutarnji list, Večernji list, Novi list, 24 sata, Glas Slavonije i Slobodna Dalmacija) u načinu kako doživljavaju predstavljene kriterije odabira vijesti u svojoj i hrvatskoj novinarskoj praksi, provedena je analiza varijance (ANOVA). Rezultati su pokazali razlike u prosječnim rezultatima između šest redakcija prema svim dimenzijama kriterija odabira vijesti, kako su ranije prikazani. Rezultati pojedinih dimenzija iskazani su kao ukupan prosječan rezultat svih čestica unutar svake dimenzije zasebno (Tablica 1.).

Rezultati su pokazali kako između šest redakcija nema značajnih razlika u prosječnim rezultatima, kada procjenjuju kriterije: javni interes, utjecaj vlasništva i dosega medija na kvalitetu i obuhvat izvještavanja, zakonodavni okvir, integrirana redakcija, globalni vs. regionalni događaji, posljedice i kontinuitet događaja te senzacionalizam. Navedene kriterije odabira vijesti, novinari svih šest analiziranih redakcija doživljavaju međusobno slično u svojoj praksi, neovisno o tome u kojim novinama pišu. No, razlike su značajne u prosječnim rezultatima kada procjenjuju kriterije: pristranost vs. nepristranost $(\mathrm{F}=2,633 ; \mathrm{p}=, 033)$, personalizaciju i ljudski interes $(\mathrm{F}=2,708 ; \mathrm{p}=, 029)$, uredničku politiku $(\mathrm{F}=3,014 ; \mathrm{p}=, 018)$, utjecaj elitnih osoba i elitnih nacija $(F=3,896 ; p=, 004)$ i utjecaj interesnih skupina $(F=2,611$; $\mathrm{p}=, 034)$.

\section{Zaključak}

Rezultati istraživanja percepcije kriterija selekcije vijesti pokazali su kako zamišljeni teorijski koncepti nisu u potpunosti vidljivi kod novinara u šest najčitanijih hrvatskih nacionalnih i regionalnih dnevnih novina. Naime, predloženi teorijski model pokazao je kako novinari pojedine koncepte ne vide na način na koji smo ih postavili, već vide širu sliku profesije, dok pojedine teorijske dimenzije u praksi ne percipiraju. 
Percepcija kriterija selekcije vijesti kod novinara u hrvatskim dnevnim novinama

To ne mora nužno značiti da analizirani koncepti u praksi ne postoje, već da nisu dohvatljivi u novinarskoj percepciji, niti se oni time opterećuju, već izvještavanjem nastoje ispuniti minimalne standarde profesije. I doista, rezultati istraživanja potvrdili su kako, generalno gledajući, nema značajnijih razlika između novinara šest promatranih redakcija prema kriterijima odabira vijesti u njihovoj praksi. No, promatrajući prosječne rezultate, uočene su značajne razlike u novinarskoj procjeni i odabiru sljedećih kriterija vijesti; pristranost vs. nepristranost, personalizacija i ljudski interes, urednička politika, utjecaj elitnih osoba i elitnih nacija, utjecaj interesnih skupina ( $P R$, oglašivači, izvori informacija). U postavci istraživanja očekivane su razlike u kriterijima odabira vijesti u praksi između novinara koji su pisali o EU i onih koji su pokrivali ostale teme. Kao što je već spomenuto, promatrajući prosječne rezultate, uočava se značajna razlika među novinarskim odabirom vezano uz kriterije: ljudski interes i personalizacija, integrirana redakcija te globalni naspram regionalnih događaja kod novinara koji nisu pisali o temama vezanima uz EU i novinarima koji su pisali o EU tematici.

$\mathrm{Na}$ temelju rezultata ankete definirani su novi kriteriji selekcije vijesti, koje bi svakako trebalo provjeriti i u budućim istraživanjima u dnevnim novinama, ali i tjednicima. Većina spomenutih teorijskih modela selekcije vijesti uglavnom nije bila empirijski provjerena u kontekstu utjecaja i djelotvornosti istih u tiskanim medijima, za razliku od televizije kao medija čija provjera teorijskog modela postoji. Govoreći o korištenoj istraživačkoj metodologiji potrebno je istaknuti kako su dobiveni rezultati pokazali razliku između novinara koji prate EU tematiku i onih koji ne prate EU tematiku prema dimenzijama kriterija selekcije vijesti. Ispitivanu bi razliku ovih dviju skupina novinara bilo zanimljivo provjeriti i na uzorku novinara ostalih medija (televizija, internetski portali...), prije svega radi boljeg razumijevanja kriterija odabira vijesti i u drugim medijima. S druge strane, proces selekcije vijesti treba promatrati i u kontekstu društvenih medija koji mijenjaju novinarsku svakodnevicu, tražeći prilagodbu novim kanalima, ali i navike konzumenata, posebice mladih koji se u odabiru medijskog sadržaja uglavnom oslanjaju na preporuke virtualnih prijatelja (Harcup i O' Neill, 2016). Dokaz je to da je nužno nastaviti s proučavanjem procesa selekcije vijesti u medijima s ciljem razumijevanja promjena u novinarskom i uredničkom odabiru u digitalnom dobu, uzimajući u obzir unutarnje i vanjske faktore utjecaja, koji nesumnjivo utječu i na percepciju vjerodostojnosti medija. 


\section{BILJEŠKE}

1 Članak donosi prikaz dijela rezultata istraživanja nastalog u sklopu doktorskog rada "Analiza medijskoga izvještavanja u hrvatskim dnevnim novinama na primjeru kampanje za izbore za Europski parlament 2014." Tanje Grmuše, izrađenog i obranjenog 26. 2. 2016. pod mentorstvom izv. prof. dr. sc. Gorana Popovića i izv. prof. dr. sc. Mihaele Banek Zorice.

2 Riječ je o sljedećim faktorima: 1) frekventnost/vrijeme, 2) prag veličine/utjecaj, 3) jasnoća/nedvosmislenost, 4) važnost, 5) suzvučje/konsonancija, 6) neočekivanost, 7) kontinuitet događaja/ tematizacija, 8) kompozicija/struktura, 9) veza s elitnim osobama, 10) veza s elitnim nacijama, 11) personalizacija, 12) negativnost (Galtung i Ruge, 1965).

3 Analizirano je 1276 članaka u sljedećim dnevnicima: Daily Telegraph, The Sun, Daily Mail (Harcup i O' Neill $(2001,262,263)$.

4 Njihovo istraživanje iz 2001. rezultiralo je suvremenom klasifikacijom kriterija vrijednosti vijesti koja uključuje sljedećih deset indikatora: moć elita, celebritiyje, zabavu, iznenađenje, loše vijesti, dobre vijesti, važnost, relevantnost, kontinuitet, agendu medijske organizacije (Harcup i O'Neill, 2001, 279). U ponovljenom istraživanju na uzorku od 10 britanskih dnevnih novina (The Sun, Daily Mail, Daily Telegraph, Daily Mirror, Daily Express, The Times, The Guardian, The Independent, Metro, Evening Standard) u kojem je fokus stavljen na novinske priče najviše dijeljene na Facebooku, navedenim kriterijima dodani su još ekskluzivnost, konflikt, audiovizualni sadržaji, djeljivost na društvenim mrežama i drama (Harcup i O’ Neill, 2016, 13).

5 Na referendumu održanom 23. 6. 2016., poznatijem i kao Brexit, 51,9 \% britanskih birača glasovalo je za izlazak iz EU-a, a 48,1 \% protiv, čime je stvorena velika neizvjesnost oko budućnosti Velike Britanije, ali i europskog projekta, čija je stabilnost u posljednjih nekoliko godina narušena međusobnim trzavicama zemalja članica oko nužnosti provođenja unutarnjih reformi Unije s ciljem prevladavanja rastućih nejednakosti među zemljama članicama.

\section{LITERATURA}

Croasmun, James, T. \& Ostrom, L. (2011) "Using Likert-Type Scales in the Social Sciences", Journal of Adult Education, 40 (1), 19-22.

Donsbach, W. (2004) "Psychology of news decisions: Factors behind Journalists' Professional Behavior", Journalism, 5 (2), 131-157.

Galtung, J. \& Ruge, M. (1965) "The structure of foreign news: the presentation of the Congo, Cuba and Cyprus crises in four Norwegian newspapers", Journal of International Peace Research 1, 64-91.

Gans, Herbert J. (1980) Deciding What's News. London: Constable.

Gliem, Joseph, A. \& Gliem, Rosemary, R. (2003) "Calculating, Interpreting, and Reporting Cronbach's Alpha Reliability Coefficient for Likert-Type Scales", Midwest Research to Practice Conference in Adult, Continuing, and Community Education, 82-88.

Harcup, T. \& O’Neill, D. (2016) “What is News?", Journalism Studies, DOI: http:// dx.doi.org/10.1080/1461670X.2016.1150193, pristupljeno: 13. lipnja 2016.

Harcup, T. \& O'Neill, D. (2001) "What is News? Galtung and Ruge revisited", Journalism Studies, 2 (2), 261-280. 
Percepcija kriterija selekcije vijesti kod novinara u hrvatskim dnevnim novinama

Heikkilä, H. \& Kunelius, R. (2006) "Journalists imagining the European public sphere. Professional discourses about the EU news practices in ten countries", Javnost - The Public, 13 (4), 63-80.

Herbert, J. (2000) Journalism in the Digital Age. Oxford: Focal Press.

Hetherington, A. (1985) News, Newspapers and Television, London: Macmillan.

Kanižaj, I. (2010) Proizvodnja vijesti u hrvatskim dnevnicima: (novinsko izvještavanje u kampanjama za parlamentarne izbore 2003. i 2007. godine): doktorska disertacija / Igor Kanižaj; mentor Ivo Žanić, Zagreb: Sveučilište u Zagrebu, Fakultet političkih znanosti.

Kunczik, M. \& Zipfel, A. (2006) Uvod u znanost o medijima i komunikologiju, Zagreb: Friedrich Ebert Stiftung.

Lee, A. M. \& Chyi, H. I. (2014) "Motivational Consumption Model: Exploring the Psychological Structure of News Use", Journalism \& Mass Communication Quarterly, 91 (4), 706-724.

Östgaard, E. (1965) "Factors Influencing the Flow of News", Journal of International Peace Research, 2 (1), 39-63.

Perišin, T. (2010) Televizijske vijesti. Zagreb: Naklada Medijska istraživanja.

Peterson, S. (1979) "Foreign news gatekeepers and criteria of newsworthiness", Journalism Quarterly, 56, 116-125.

Picard, R. G. (2010) Value Creation and the Future of News Organizations; Why and how journalism must change to remain relevant in the twenty first century, Barcelona/Sevilla: Formalpress/Media XXI - Publishing, Research and Consulting.

Popović, G. \& T. Grmuša \& H. Prpić (2014) "Upravljanje informacijama i znanjem na primjeru kampanje za izbore za Europski parlament 2013.”, 461-477. U: M. Plenković et al.: Društvo i tehnologija 2014 - dr. Juraj Plenković/ Society and Technology 2014 - dr. Juraj Plenković. Zagreb. Međunarodna federacija komunikoloških društava/International Federation of Communication Associations, Hrvatsko komunikološko društvo/Croatian Communication Association, Alma Mater Europaea - Europski centar Maribor/Alma Mater Europaea - European Center Maribor.

Popović, G. \& T. Grmuša \& H. Prpić (2012) "Referendumska kampanja oko ulaska Hrvatske u EU - informiranje ili propaganda?", 60-61. U: D. Mustić: Društvo $i$ tehnologija 2013 - dr. Juraj Plenković/Society and Technology 2013 - dr. Juraj Plenković. Zagreb. International Federation of Communication Associations IFCA, Croatian Communication Association - CCA, Alma Mater Europaea European Center Maribor (AMA - ECM).

Popović, G. \& T. Grmuša \& H. Prpić (2011) “Izvještavanje o Europskoj uniji u hrvatskim dnevnim novinama: završetak hrvatskih pristupnih pregovora", Informatologia, 44 (4), 309-322. 
Prpić, H. \& Popović, G. \& Hadžić, S. (2011) "Istraživanje informativnih vrijednosti u političkom dnevniku Vjesnik", 322-332. U: M. Plenković et al.: Društvo i tehnologija 2011 - Society and Technology. Zagreb. Međunarodna federacija komunikoloških društava/International Federation of Communication Associations, Hrvatsko komunikološko društvo/Croatian Communication Association.

Tkalac Verčič, A. \& Sinčić Ćorić, D. \& Pološki Vokić, N. (2013) Priručnik za metodologiju istraživačkog rada u društvenim istraživanjima: kako osmisliti, provesti $i$ opisati znanstveno i stručno istraživanje. Zagreb: M.E.P., d. o. o.

Tunstall, J. (1971) Journalists at Work. London: Constable.

Vilović, G. (2011) "Novinarska profesija", 116-134. U: Z. Peruško: Hrvatski medijski sustav: Prema UNESCO-vim indikatorima medijskog razvoja. Zagreb. FPZ, Biblioteka Hrvatska politologija.

Zoroja, J. (2014) "Primjena faktorske analize u istraživanju korištenja informacijsko-komunikacijskih tehnologija: primjer europskih zemalja", Zbornik Ekonomskog fakulteta u Zagrebu, 12 (1), 59-78. 


\title{
Perception of News Selection Criteria by Journalists in Croatian Daily Newspapers
}

\author{
Tanja Grmuša \\ Goran Popović \\ Mihaela Banek Zorica
}

\section{SUMMARY}

The selection of news is at the center of the study of various authors, especially because of the variability of news values indicators which affect the journalist's decision about which event is going to be published. However, most previous authors examined that process from the theoretical aspect (Galtung and Ruge, 1965, Schulz, 1975, Gans, 1980), while a few of them did empirical tests (Kanižaj, 2010; Perišin, 2010; Prpić, Popović, Hadžić, 2011). A special challenge thereby is monitoring specific areas such as the EU topics, which often remain in the shadow of the national topics. The paper presents the results of the research of perception of news selection indicators divided into internal and external criteria, whose suitability and applicability was appraised by journalists in six widely read daily newspapers - Jutarnji list, Večernji list, 24 sata, Novi list, Slobodna Dalmacija and Glas Slavonije. The research, that was conducted at the end of October and in early November 2014, by online survey on a sample of $\mathrm{N}=62$ journalists divided into two groups journalists who cover EU topics and journalists who cover other topics, found that the journalist's imaginary theoretical concept evaluate in the broader context of professional standards. At the same time, the results have shown that there were no significant differences between the journalists from the six observed newsrooms, but according to the average scores, there were some differences in news selection by following criteria: bias vs. impartiality, personalization and human interest, editorial policy, the impact of elite people and elite nations and the influence of interest groups. Also, the research showed that there are differences between the journalists who cover the EU and journalists who cover other topics in four analyzed indicators: human interest and personalization, integrated newsroom and global vs. regional events.

Key words: news selection, news value, EU topics, daily newspaper, journalists 